\title{
Hasta-Hekim Yönelim Ölçeğinin (HHYÖ) Türkçeye uyarlanmasi
}

\section{Translation and validation of the Patient-Practitioner Orientation Scale in Turkey}

Serdar Özdemir ${ }^{1}$, Tamer Edirne ${ }^{2}$

${ }^{1}$ Yeditepe Üniversitesi Tıp Fakültesi

${ }^{2}$ Pamukkale Üniversitesi Tıp Fakültesi

\author{
Anahtar Sözcükler: \\ Hasta hekim ilişkisi, \\ hasta merkezli yaklaşım, \\ geçerlik, güvenirlik \\ Keywords: \\ Patient doctor relationship, \\ patient centeredness, \\ validity, reliability
}

\section{ÖZET:}

Amaç: Bu çalışmada orijinal ismi The Patient-Practitioner Orientation Scale olan Hasta-Hekim Yönelim Ölçeğinin (HHYÖ) Türkçeye uyarlanması amaçlanmıştır. Buna göre ölçeğin Türkçe formunun orijinal İngilizce form ile dilsel eşdeğerlik taşıdığı, benzer geçerlik, güvenirlik ve faktör yapısına sahip olduğu hipotezleri sınanmıştır.

Yöntem: Araştırmada öncelikle 18 maddeden oluşan ölçek çeviri-geri çeviri yöntemi ile Türkçeye çevrilmiştir. Çevirinin dilsel eşdeğerliği iki dilli grup deseni kullanılarak test edilmiştir. Bunun için İngilizce bilen tıp fakültesi öğrencilerine $(n=71)$ test-tekrar test yöntemine göre uygulanan ölçeğin kaynak ve hedef dildeki maddeleri arasındaki ilişkiler Spearman korelasyon katsayısı ile incelenmiştir. Geçerlik ve güvenirlik analizleri için Türkçe ölçek iki farklı tıp fakültesindeki 1. sınıf öğrencilerine $(n=379)$ uygulanmıştır. Ölçeğin yap1 geçerliğini ortaya koymak amacıyla Açımlayıcı Faktör Analizi ve Doğrulayıcı Faktör Analizi yapılmıştır. Güvenirlik analizi Cronbach Alfa iç tutarlılık katsayısı hesaplanarak yapılmıştır.

Sonuçlar: Hasta Hekim İlişkisine Yönelik Tutum Ölçeğinde yer alan maddelerin orijinal maddeler ile 0.41 ile 0.71 arasında $(\mathrm{p}<0,01)$ anlamlı dilsel eşdeğerlik gösterdikleri saptanmıştır. İlk açımlayıcı faktör analizinde faktörlerin içerisine oturmayan ve faktör ağıllıkları 0,25 'den düşük olarak saptanan dört madde dışarıda bırakılmıştır. Geriye kalan 14 madde ile yapılan ikinci analizin sonucuna göre Türkçe maddelerin orijinal ölçekte yer alan maddeler ile benzer yük aldıkları görülmüştür. Ölçeğin toplam Cronbach Alfa değeri 0.80, paylaşım alt boyutu için bu değer 0,732; bakım alt boyutu için ise 0,653 hesaplanmış ve kabul edilebilir düzeyde bulunmuştur.

Tartışma: Bu sonuçlara göre Hasta-Hekim Yönelim Ölçeğinin Türkiye'deki araştırmalarda kullanılabilecek, dilsel eşdeğerliğe sahip, geçerli ve güvenilir bir ölçme aracı olduğu söylenebilir. 


\section{ABSTRACT:}

Background: The Patient-Practitioner

Orientation Scale is designed to compare a patient-oriented approach with a doctororiented approach among medical staff.

Aims: The aim of this study is to adapt the Patient-Practitioner Orientation Scale to Turkish. The hypotheses that the Turkish version shows linguistic equivalence and comparable validity, reliability and factor load were tested.

Study design: This descriptive correlational study describes the translation process and exploratory and confirmatory factor analyses of the Patient-Practitioner Orientation Scale.

Methods: The original scale was first translated into Turkish using translation-back translation method. Linguistic equivalence was tested by bilingual groups design through conducting the scale to English speaking first term medical students and comparing original and target scale items by Spearman correlation coefficient. Medical students $(n=379)$ from two medical schools in Turkey were enrolled in the study to complete the Turkish scale in order to test validity and reliability. Exploratory and confirmatory factor analyses were completed to evaluate structure validity. Cronbach Alpha values were defined for internal consistency.

Results: Items in the Turkish version compared to the original scale items showed a relation between 0.41 and $0.71 \quad(p<0.01)$ verifying linguistic equivalence. Primary exploratory factor analysis revealed that four items did not achieve a loading factor of 0.30 and these items were excluded. After factor analysis and tests of internal consistency, a shortened version with 14 items was formed (PPOS - T14). Cronbach's alpha coefficients were 0.800 for the entire sample group, 0.732 for the sharing domain and 0.653 for the caring domain and were found adequate.

Conclusions: The Turkish form of the PPOS showed linguistic equivalence, satisfactory validity and acceptable reliability. PPOS - T14 is a reliable tool to evaluate patient-centeredness between medical students in Turkish-speaking countries.

Gönderme Tarihi / Submitted :08.11.2017

Kabul Tarihi / Accepted : 14.02.2018

\section{Introduction:}

Every encounter of the patient with the physician is a relationship with unique features where the main task is to relieve pain and suffering. If the relationship during the consultation between a physician and the patient involves authoritarian or biomedical characteristics, this can be called a doctor-centered or disease centered care (1). If the relationship exhibits an egalitarian, or biopsychosocial model, it is called patientcentered care (2). Managing such a relationship requires the doctor using communication skills that search the patients' reasons for the visit, worries and expectations and feelings and emotions. The doctor is expected to approach to the patient as a whole person and achieve a management plan through shared decision while enhancing the relationship (3). Reports from studies in health care and medical education state the importance of promoting patientcentered attitudes among caregivers. Studies have revealed that patient-centered care is related with higher satisfaction skores, better therapeutic adherence, reduced malpractice claims, decreased adverse effects and lower 
costs (4-6). The roles of physicians, medical students and patients concerning their attitudes have been assessed with numerous instruments in medical care. One of the several scales that evaluate physician attitudes is the PatientPractitioner Orientation Scale (PPOS) (7), which compares a patient-oriented attitude with a doctor-oriented attitude, and is used in several countries around the world (8-10). The need for a translation of the PPOS in non-English languages demands an important challenge for to produce an instrument as valid and reliable as the original one.

The aim of this study is to adapt the PatientPractitioner Orientation Scale to Turkish. We tested the hypotheses that the Turkish version of this instrument shows acceptable reliability, psychometrically and linguistically validity and culturally relevantness.

\section{Material and Methods}

Ethics approval and consent to participate

After obtaining permission from the author of the original PPOS, ethical approval was acquired from the Ethical Review Committee of the Faculty of Medicine of Pamukkale University, Denizli. Verbal consent was obtained from all participants before administering the instrument.

\section{Description of the instrument}

The PPOS is a self-administered questionnaire in English which contains 18 items of which nine assess caring attitudes and nine assess sharing attitudes. The caring domain refers to the belief about the importance of emotions, interpersonal relationships and considering patients' preferences. The sharing domain measures whether the practiotioner is willing to share information, power and control in decisionmaking with the patient. PPOS responses are evaluated by a six-point Likert scale (strongly agree to straongly disagree) and average scores are graded and divided into three groups: high scores (patient-centred, with a mean 5.00 or greater), medium scores (greater than 4.57 but less than 5.00) and low scores (doctor-centered, mean of 4.57 or less) (4).

\section{Translation and cultural adaptation}

The process of translation was carried out following guidelines according to our purpose $(11,12)$. We performed translation into Turkish simultaneously and independently by two bilingual translators. A document in Turkish was created using the original scale as a template by the authors. The back translation was done by an independent translator who was a Turkish teacher in English language sciences. The backtranslated version was sent to two external bilingual reviewers (two teachers experienced in translating instruments from the Pamukkale University, School of English Language Education), for comparison and suggestions were recorded. With the aim of retrospective and cognitive assessment, 25 students were invited to discuss about every item of the questionnaire and appropriate changes were accepted according to suggestions (11). These interviews were conducted at appropriate rooms in the faculty by the authors. After assessing recommendations, the translated pre-final version of PPOS-T18 was pre-tested on a sample of 71 students. The pre-test was carried out using a bi-lingual design method (13). Four questionnaires were prepared; two containing a hybrid language (English-Turkish) and (Turkish-English) and one in English and one in Turkish. The students were divided into four groups and completed the hybrid and the single language forms. The same students completed the counterpart forms after an interval of two weeks, in order to test internal consistency and test-re-test reliability 
(Figure 1). Original and target language item correlations were analysed using Spearman Correlation coefficient. Students were invited to participate at appropriate times (after lessons, during lunch time etc.) and asked to return the completed questionnaires by using boxes placed in easy accessible areas. After approval of existing lingual equivalence, we proceeded for validity and reliability analysis.

\section{Validation analysis}

For the validation analysis, a total of 379 first year medical students (132 from Pamukkale University in Denizli and 247 from İstanbul University, İstanbul Medical School) were included. The sample size was defined by suggestions indicating a requirement for 20 respondents per item. Since there were 18 items on the questionnaire, the sample size was considered to be $n=360$. In order to avoid sample attrition, 20 individuals were added to the sample size (14). With this aim, first year medical students were invited according to convenience sampling method. After obtaining verbal consent, medical students completed the PPOS-T18 and a questionnaire exploring sociodemographic data. Missing responses $(\geq 2)$ were accepted as an exclusion criterion.

In order to determine validity, we used factor analysis (exploratory and confirmatory) to validate and define the correlation between variables and factors (factor loadings).

We started with assessing the appropriateness of the variables for factor analysis with the KaiserMeyer-Olkin (KMO) index and the Bartlett's test of Sphericity (BTS) to define the factorability of the correlation matrix. Satisfaction for analysis was considered as a factor loading $>$ 0.60 for KMO and test significance for BTS. For the $\mathrm{x} 2 / \mathrm{df}$ ratio, values between 2 and 3 are recommended $(15,16)$.

To assess if a scale is associated with variables which are suggested to be correlated with what the scale is intended to measure, one have to verify the correlation between variables and factors (factor loadings) and values lower than 0.30 are considered not to be satisfactory (for sample sizes >350) (17). Confirmatory factor analysis (CFA) was confirmed with Varimax rotation applying maximum likelihodd analysis and the adjustment indices of the model: GFI (Goodness-of-Fit Index), NFI (Normed Fit Index), RFI (relative fit index), SRMR (Standardized Root-Mean-Squared Residual), RMSEA (Root-Mean-Square Error of Approximation), and CFI (Comparative Fit Index).

For GFI, CFI, IFI, RFI and NFI, values $\geq 0.90$ indicate an adequate adjustment, for RMSEA, values $\leq 0.06$ suggest a good model fit, and for SRMR, values $\leq 0.08$ suggest a good model fit $(90 \%$ confidence intervals $(\mathrm{CI})$ and $\mathrm{p}<$ $0.10)(17-19)$. Statistical significance was set at $\mathrm{P}<0.05$. We conducted statistical analyses with SPSS 16.0 (SPSS for Windows, Version 16.0. Chicago, SPSS Inc.) and LISREL 8.80 ( LISREL for Windows, Lincolnwood, IL: Scientific Software International, Inc.)

\section{Reliability analysis}

Cronbach's alpha coefficient was calculated in order to determine reliability and values $>0.5$ were used. To establish test-retest reliability, intraclass correlation coefficient were assessed using the scores from a sample of 71 medical students twice in two weeks. Reliability was considered as being poor if intraclass correlation coefficient values were $<0.4$, moderate to high if $0.4-0.75$ and excellent if $>0.75$ (20).

\section{Results}

\section{Translation and cultural adaptation}

Spearman analysis revealed that all items in 
the Turkish and English versions were showing correlation coefficient values between 0.41 and 0.71 and a statistical significant relationship of $\mathrm{P}<0.01$ satisfying the authors with the face validity of the PPOS-T (Table 1).

\section{Reliability}

The following Cronbach's alpha coefficient for internal consistency were confirmed:

0.800 for the entire sample group, 0.732 for the sharing domain and 0.653 for the caring domain.

\section{Exploratory factor analysis}

In the EFA, as a result of the primary analysis, the Varimax rotation analysis revealed a twofactor solution for 18 items that explained $35.49 \%$ of the variance. Four items (3, 4, 14, and 17) showed loadings below 0.30 and were eliminated, leaving 14 items (Annex 1). After the secondary analysis, the value of the correlation matrix determinant was not zero (0.069), the KMO index was 0.855 and the Bartlett's sphericity test $\mathrm{X}^{2}$ value was 995,287 $(p<0,001)$. Repetition of a analysis with the retained 14 items resulted in a 2 -factor solution that explained $40,52 \%$ of the overall variance. Factor loading was highest for item 18 with 0.75 and lowest for item 12 with 0.36 (Table 2).

\section{Confirmatory factor analysis}

The global adjustment of the model created the resulting fit statistics: $\mathrm{X}^{2}=198,84$, df $=76, \mathrm{p}$ $=0,0001 ; \mathrm{X}^{2} / \mathrm{df}=198,84 / 76=2,61 ; \mathrm{NFI}=$ 0,$90 ; \mathrm{CFI}=0,93$; IFI $=0,93 ; \mathrm{RFI}=0,88$; GFI $=0,92 ;$ RMSEA $=0,071$ and $\operatorname{SRMR}=0,058$. The goodness-of-fit values were within or close to the ranges that propose a satisfactory fit of the limited model to the data (18).

\section{Discussion}

These findings indicate that the Turkish version of the PPOS (PPOS-T14) has satisfactory reliability and validity. It is therefore suitable for evaluating attitudes of Turkish health practitioners regarding patient-centeredness.

We followed guidelines aiming accurate content and semantic equivalence and tested it in its own cultural context $(11,21)$. With this purpose, we designed a model of four groups using a bilingual design method and evaluated the Turkish version by test-retest method in two weeks. The reliability of the test-retest results was accepted good, suggesting the presence of temporal stability of the Turkish scale.

Internal consistency was documented to be acceptable (Cronbach's alpha $=0.800$ for the entire sample group, 0.732 for the sharing domain and 0.653 for the caring domain).

Alpha values of $>0.7$ are regarded as satisfactory, and although our total and sharing alpha scores are within the anticipated ranges, the alpha score for caring is questionable (22). Nevertheless, some researchers have concluded that values above 0.6 can be accepted as displaying satisfactory internal validity, when the majority of scores have alpha values over $0.7(23,24)$.

The total alpha value is higher in our study than the values by Pereira et al. (Cronbach's alpha = 0.60 for the entire sample group; 0.46 for the caring domain and 0.49 for the sharing domain, Mudiyanse et al. (Cronbach's alpha $=0.63$ total; 0.46 for the caring and 0.50 for the sharing domain), and Kiessling et al. (Cronbach's alpha $=0.76$ total; 0.66 for the caring and 0.64 for the sharing domain) who translated and adapted the PPOS into their languages (25-27).

The subdomain alpha scores were substantially lower than the total alpha score in this study, which was also a common finding. The reason for this could be the reduced number of the items, in addition to to the lack of effect of 
correlation between domains $(28,29)$.

In the exploratory factor analysis, our results were similar to the original scale and most items had had a satisfactory factor loading. Nevertheless, items 3, 4, 14 and 17 had factor loadings below 0.30 and were accepted as inadequate. These items were eliminated producing a scale of 14 items.

In the caring subdomain (factor 1), items 5, 8, 9, $10,15,18$ and in the sharing subdomain (factor 2), items $2,6,7,11,16$, showed factor loadings greater than 0.50 , providing evidence for a better representation. Item 1 and 12 (sharing) had factor loadings of 0.47 and 0.36 , respectively, and item 13 (caring) had a factor loading of 0.38 , but, similar complexities were reported in the original and other adapted versions and therefore were not accepted as reason of cultural alterations.

Our confirmatory factor analysis demonstrated that the configuration of the hypothesized twofactor model was reliable with the data and that the model supplied adequate fit with the discovered variables.

A major limitation of this study is the reduced number of the Turkish scale items compared to the original English version. However, similar reductions were made in other translation and validation studies which may reveal a cultural need or necessity (27). Another limitation of the study is that our sample of medical students may not be representative of the whole population and as we did not included patients. Therefore, this scale should be used with caution in this group. Nevertheless, the high total Cronbach's alpha value of the PPOS-T14 is a strong indicator for the instrument to produce accurate measurements and generate reliable and valid data.

The PPOS - T14 shows acceptable validity and adequate reliability and therefore, it can be used in studies to evaluate the attitudes of medical students towards patient-centeredness in Turkish speaking countries. In the absence of a gold standart to assess the criterian validity of the Turkish version and results from studies with doctors and patients, it can also be used in other health profession members.

\section{Acknowledgement}

We thank Hacer Nalbant, who works at İstanbul Faculty of Medicine, Department of Medical Education, for distributing and collecting questionnaires.

\section{Conflict of interest}

The authors declare no conflict of interest.

\section{REFERENCES}

1. Balint E. The possibilities of patient-centered medicine. J R Coll Gen Pract 1969;17(82):26976.

2. Hudon C, Fortin M, Haggerty JL, Lambert M, Poitras ME. Measuring patients' perceptions of patient-centered care: A systematic review of tools for family medicine. Ann Fam Med 2011;9:155-64.

3. Stewart M. Towards a global definition of patient-centred care. Br Med J 2001;322:444-5.

4. Robinson JH, Callister LLC, Berry JA, Dearing KA. Patient-centered care and adherence: Definitions and applications to improve outcomes. J Am Acad Nurse Pract 2008;20:600-7. 
5. Stewart M, Brown JB, Donner A, McWhinney IR, Oates J, Weston WW, et al. The impact of patient-centered care on outcomes. J Fam Pract 2000;49(9):796-804.

6. Levinson W, Lesser CS, Epstein RM. Developing physician communication skills for patient-centered care. Health Affair (Millwood) 2010;29:1310-8.

7. Krupat E, Hiam CM, Fleming MZ, Freeman P. Patient-centeredness and its correlates among first year medical students. Int J Psychiatry Med 1999;29(3):347-56.

8. Moore M. What does Patient-centred communication mean in Nepal? Med Educ 2008;42:18-26.

9. Tsimitou Z, Kerasidou O, Efstathiou N, Papaharitou S, Hatzimouratidis K, Hatzichristou D. Medical students' attitudes toward patientcentered care: A longitudinal survey. Med Educ 2007;41:146-53.

10. Madhan B, Rajpurohit AS, Gayathri H. Attitudes of postgraduate orthodontic students in India towards patient-centred care. J Dent Educ 2011;75(1):107-14.

11. Eremenco SL, Cella D, Arnold BJA. Comprehensive method for the translation and cross-cultural validation of health status questionnaires. Eval Health Prof 2005;28:21232 .

12. Terwee CB, Bot SD, de Boer MR, van der Windt DA, Knol DL, Dekker J, et al. Quality criteria were proposed for measurement properties of health status questionnaires. J Clin Epidemiol 2007;60:34-42.
13. Hambleton RK, Merenda PF, Spielberger CD. Adapting Educational and Psychological Tests for Cross-Cultural Assessment. New Jersey, London, Lawrence Erlbaum Assoc., Publishers, 2005.

14. Hair JF, Tatham RL, Anderson RE, Black W. Multivariate data analysis, 6th ed., New Jersey: Prentice Hall; 2006.

15. Howell DC. Statistical Methods for Psychology. Florence: Cengage Learning Services, 2009.

16. Coakes SJ, Steed LG. SPSS Analysis without Anguish: Version 14.0 for Windows. Milton, Queensland: John Wiley \& Sons Australia Ltd., 2007.

17. Kahn JH. Factor analysis in counseling psychology research, training, and practice: principles, advances, and applications. Couns Psychol 2006;34: 684-718.

18. Hooper, D., Coughlan, J. and Mullen, M. R. Structural Equation Modelling: Guidelines for Determining Model Fit. Electronic Journal of Business Research Methods 2008;6(1):5360. (cited 12 May 2016) Available from: http://arrow.dit.ie/cgi/viewcontent. cgi? article $=1001 \&$ context=buschmanart

19. Weston R, Gore PA. A brief guide to structural equation modeling. Couns Psychol 2006;34:684-718.

20. Terwee CB, Bot SD, de Boer MR, van der Windt DA, Knol DL, Dekker J, Bouter LM, de Vet HC. Quality criteria were proposed for measurement properties of health status 
questionnaires. J Clin Epidemiol 2007;60(1):3442.

21. Beaton DE, Bombardier C, Guillemin F, Ferraz MB. Guidelines for the process of crosscultural adaptation of self-report measure. Spine 2005;25:3186-3191.

22. George D, Mallery P. SPSS for Windows step by step: A simple guide and reference. 11.0 update (4th ed.). Boston: Allyn \& Bacon, 2003.

23. McKinley RK, Manku Scott T, Hastings AM, French DP, Baker R. Reliability and validity of a new measure of patient satisfaction with out of hours primary medical care in the United Kingdom: development of a patient questionnaire. BMJ 1997;314:193-8.

24. Bosma H, Marmot MG, Hemingway H, Nicholson AC, Brunner E, Stansfield SA. Low job control and risk of coronary heart disease in Whitehall II (prospective cohort) study. BMJ 1997; 314:558-65.

25. Pereira CM, Amaral CF, Ribeiro MM, Paro HB, Pinto RM, Reis LE, Silva CH, Krupat E. Cross-cultural validation of the PatientPractitioner Orientation Scale (PPOS). Patient Educ Couns 2013;91:37-43.

26. Mudiyanse RM, Pallegama RW, Jayalath T, Dharmaratne S, Krupat E. Translation and validation of Patient-Practitioner Orientation Scale in Sri-Lanka. Education for Health 2015;28(1):35-40.

27. Kiessling C, Fabry G, Rudolf Fischer M, Steiner C, Langewitz WA. German translation and construct validation of the Patient-ProviderOrientation Scale (PPOS-D12). Psychother
Psychosom Med Psychol 2014;64:122-7. doi:10.1055/s-0033-1341455.

28. Green SB, Lissitz RW, Mulaik SA. Limitations of coefficient alpha as an index of test unidimensionality. Educ Psychol Meas. 1977;37:827-38.

29. Cortina JM. What is coefficient alpha: an examination of theory and applications.J Appl Psychol. 1993;78:98-104. 
Table 1. PPOS-TR14 item to total correlations

\begin{tabular}{|c|c|c|c|c|c|c|c|}
\hline $\begin{array}{c}\text { Item } \\
\text { No }\end{array}$ & $\mathbf{n}$ & $\begin{array}{c}\text { Spearman's } \\
\text { rho }\end{array}$ & $\mathbf{p}$ & Item No & $\mathbf{n}$ & $\begin{array}{c}\text { Spearman's } \\
\text { rho }\end{array}$ & $\mathbf{p}$ \\
\hline 1 & 71 & .55 & $<.01$ & 10 & 71 & .48 & $<01$ \\
\hline 2 & 71 & .41 & $<.01$ & 11 & 71 & .44 & $<01$ \\
\hline 5 & 71 & .52 & $<.01$ & 12 & 71 & .53 & $<01$ \\
\hline 6 & 71 & .54 & $<.01$ & 13 & 71 & .71 & $<01$ \\
\hline 7 & 71 & .69 & $<.01$ & 15 & 71 & .58 & $<01$ \\
\hline 8 & 71 & .61 & $<.01$ & 16 & 71 & .69 & $<.01$ \\
\hline 9 & 71 & .57 & $<.01$ & 18 & 71 & .54 & $<01$ \\
\hline
\end{tabular}

PPOS = Patient-Practitioner Orientation Scale

Table 2. Factor loadings of PPOS-T14 items according to Verimax rotation method

\begin{tabular}{|l|l|l|l|}
\hline Item No & Factor 1 & Factor 2 & Variance \\
\hline 18 & 0,755 & & \\
\hline 9 & 0,657 & & \\
\hline 8 & 0,589 & & \\
\hline 10 & 0,583 & & \\
\hline 5 & 0,534 & & \\
\hline 15 & 0,593 & & \\
\hline 1 & 0,474 & & \\
\hline 12 & 0,361 & & $29,11 \%$ \\
\hline 11 & & 0,711 & \\
\hline 16 & & 0,644 & \\
\hline 6 & & 0,617 & \\
\hline 7 & & 0,573 & \\
\hline 2 & & 0,511 & \\
\hline 13 & & & $11,41 \%$ \\
\hline
\end{tabular}

PPOS-T14 = Patient-Practitioner Orientation Scale Turkish version with 14 items 
Figure 1. Flow-chart demonstrating translation and validation process of PPOS-T14

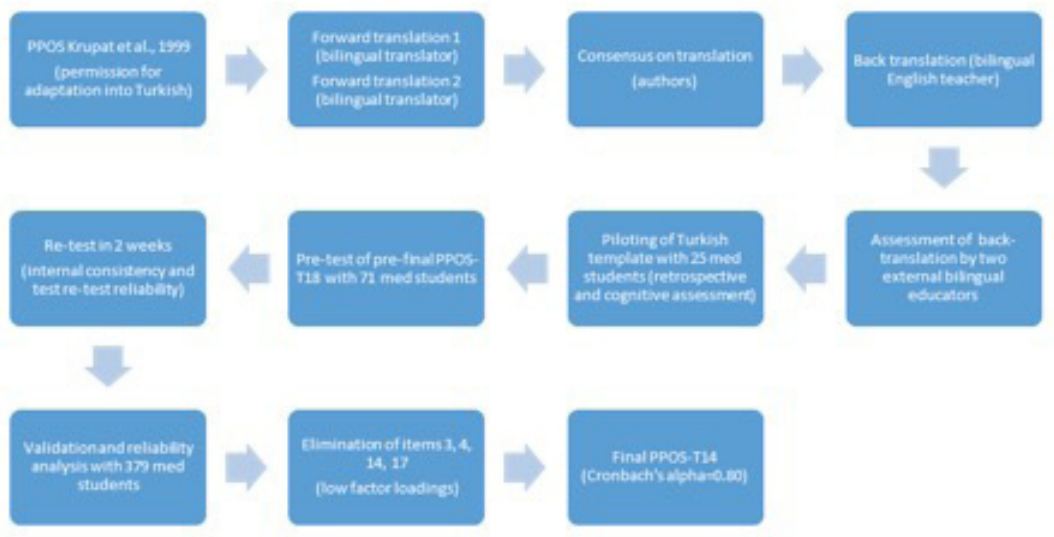

Annex 1. PPOS-TR14 scale (in Turkish)

Aşağıda hekimler, hastalar ve sağlık hizmetlerine ilişkin kişilerin düşünceleri ile ilgili ifadeler yer almaktadır. Her bir ifadeyi okuduktan sonra sizin için en uygun olan rakamı aşağıdaki puanlamaya göre işaretleyiniz. Adınızı belirtmenize gerek yoktur. Katkılarınız için teşekkür ederiz.
6. Kesinlikle katılmiyorum
5. Katılmiyorum
4. Az da olsa katılmiyorum
3. Az da olsa katıliyorum
2. Katiliyorum
1. Kesinlikle katıliyorum 


\section{Hasta-Hekim Yönelim Ölçeği [Türkçe Uyarlaması (PPOS-TR14)]}

1. Muayene sırasında neyin konuşulacağına hekim karar vermelidir.

Kesinlikle katılmıyorum 654321 Kesinlikle katılıyorum

2. Günümüzde sağlık hizmetlerinin birey merkezli olmaktan uzaklaşması, tıp alanındaki ilerlemeler için ödenmesi gereken küçük bir bedeldir.

Kesinlikle katılmıyorum 654321 Kesinlikle katılıyorum

3. Hastalar hekimlerine güvenmeli ve kendi başlarına sağlık durumları hakkında bilgi edinmeye çalışmamalıdırlar.

Kesinlikle katılmıyorum 654321 Kesinlikle katılıyorum

4. Hekimler hastalarına özgeçmişleri hakkında çok soru sorduklarında, onların özel hayatına gereğinden fazla karışmış olurlar.

Kesinlikle katılmıyorum 654321 Kesinlikle katılıyorum

5. Eğer hekim tanı ve tedavide gerçekten iyi ise, hasta ile nasıl bir ilişki kurduğunun bir önemi kalmaz.

Kesinlikle katılmıyorum 654321 Kesinlikle katılıyorum

6. Pek çok hasta yeni bir şey öğrenmiyor olsa bile soru sormaya devam eder.

Kesinlikle katılmıyorum 654321 Kesinlikle katılıyorum

7. Hekimler hastalara kendileri ile eşit güç ve konumda olan biri gibi davranmalıdırlar.

Kesinlikle katılmıyorum 654321 Kesinlikle katılıyorum

8. Hastalar genellikle sağlıkları hakkında bilgi verilmesi yerine, iyi olduklarına dair güvence verilmesini isterler.

Kesinlikle katılmıyorum 654321 Kesinlikle katılıyorum

9. Hastalarına karşı açık sözlü ve samimi davranan hekimler genelde başarılı olamazlar.

Kesinlikle katılmiyorum 654321 Kesinlikle katılıyorum

10. Hastanın hekimi ile hemfikir olmaması, ona güven ve saygı duymadığının bir göstergesidir.

Kesinlikle katılmıyorum 654321 Kesinlikle katılıyorum

11. Hastanın yaşam tarzı ve değerleri ile uyuşmayan tedavi planı başarılı olamaz.

Kesinlikle katılmıyorum 654321 Kesinlikle katılıyorum 
12. Hasta yetkinin her zaman hekimin elinde olduğunun farkında olmalıdır.

Kesinlikle katılmiyorum 654321 Kesinlikle katıliyorum

13. Hastayı tedavi etmek için onun kültürel altyapısını ve geçmişini bilmek o kadar da önemli değildir.

Kesinlikle katılmıyorum 654321 Kesinlikle katıliyorum

14. Hastaların kendi başlarına tıbbi bilgiler edinmeleri, genellikle yardımcı olmaktan çok onların kafalarını karıştırır.

Kesinlikle katılmıyorum 654321 Kesinlikle katıliyorum

\section{Puanlama}

PPOS-TR14 puanları ortalama puanlar olarak değerlendirilir ve hastaların ve sağlık çalışanlarının yönelimlerini bir veya iki madde çıkarılsa bile değerlendirmeye uygundur. Toplam ortalama puan tüm maddeler için hesaplanabildiği gibi, alt başlık ortalama puanları da hesaplanabilir. Toplam puan hasta merkezli ile doktor veya hastalık merkezli olmak arasında yer alır. Puan ne kadar yüksekse, yönelim o kadar hasta merkezlidir. Ölçeğin Paylaşım ve Bakım alt ölçek puanları da ayrıca hesaplanabilir.

Paylaşım puanları katılımcının a) hasta ve hekim güç ve kontrolü eşit olarak paylaşmalı ve b) hekimler bilgilerini hastaları ile mümkün olduğu kadar çok paylaşmalı düşüncesine ne kadar katıldığını yansıtır.

Bakım puanı katılımcının a) muayenede duyguların ele alınması ve kişiler arası ilişkinin önemli olduğuna ve b) hekimlerin hastalarına bir hastalık tablosu olarak değil de, bir birey olarak bakmaları gerektiğine ne kadar katıldığıını yansıtır.

\section{Maddelerin ölçümü}

Ölçeğin son halindeki sıralamaya göre alt boyutları oluşturan maddeler şöyledir; Paylaşım alt ölçeği 8 maddeden oluşmakta olup bu maddeler 1, 3, 6, 7, 8, 10, 12 ve 14; Bakım alt ölçeği 6 maddeden oluşmakta olup bu maddeler, 2, 4, 5, 9, 11 ve 13'tür.

Altılı Likert ölçeği soldan sağa kesinlikle katılmıyorum ile kesinlikle katılıyorum olarak hazırlanmalıdır. Kesinlikle katılmıyorum (en solda) altı (6) puan, kesinlikle katılıyorum (en sağda) bir (1) puan ile puanlanır. İki madde ters puanlanmalıdır: 7 ve 11. Böylece, yüksek puan hasta merkezli yönelimi yansıtır. Ölçekten en az 14, en fazla 84 puan alınabilir. 